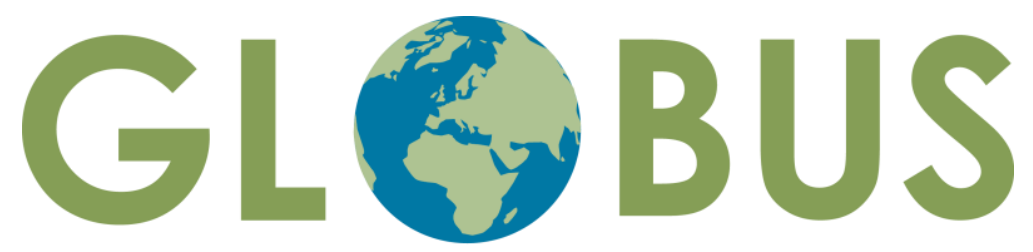

Reconsidering European Contributions to Global Justice

\title{
Towards Global Justice with Chinese Characteristics
}

Matthieu Burnay and Marta Hermez

GLOBUS Research Papers

10/2018 - July 2018 
Matthieu Burnay and Marta Hermez

Towards Global Justice with Chinese Characteristics

GLOBUS Research Paper 10/2018

July 2018

(C) Matthieu Burnay and Marta Hermez

GLOBUS Research Papers (online) | ISSN: 2535-2504

http: //www.globus.uio.no/publications/globus-research-papers/

Matthieu Burnay is Lecturer (Assistant Professor) in Global Law and Chinese Law at Queen Mary University of London

Marta Hermez is Junior Researcher at the Leuven Centre for Global Governance Studies at the University of Leuven.

Reconsidering European Contributions to Global Justice (GLOBUS) is a research project that critically examines the EU's contribution to global justice.

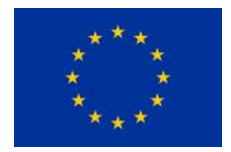

Funded by the European Union's Horizon 2020 programme. This work is the sole responsibility of the author. It does not reflect the opinion of the EU. The Research Executive Agency is not responsible for any use that may be made of the information it contains.

\section{www.globus.uio.no}

E Twitter:@globus_h2020

f Facebook:@globus.h2020

Issued by:

ARENA Centre for European Studies

University of Oslo

P.O. Box 1143 Blindern

0318 Oslo, Norway

www.arena.uio.no

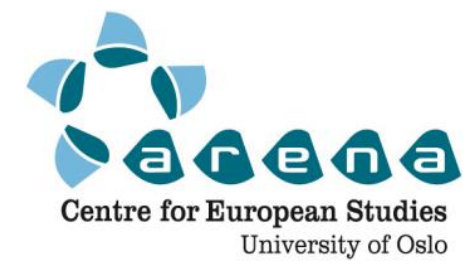




\section{Abstract}

This paper aims to contextualise China's own understanding of global justice in global governance. The paper does not only uncover China's traditional understanding of justice and global justice as purveyors of order and stability, it also analyses the very pragmatic and instrumental Chinese views on the global institutional order that should be conducive to that ideal. This pragmatic and instrumental stance is obvious in China's support for a restrictive understanding of the sovereignty concept; ambiguous support for a reform of the global governance architecture; and preference for non-binding settlements to resolve international disputes. The paper demonstrates that China's approach to and appreciation of the South China Sea Arbitration is exemplary thereof. The paper also argues that there is a real momentum for the EU to further engage with China in support of the strengthening global justice.

\section{Keywords}

China, global governance, global justice, South China Sea

Research for this paper has received funding from the European Union's Horizon 2020 research and innovation programme under grant agreement no. 693609 (GLOBUS). 


\section{Introduction}

Until the $20^{\text {th }}$ century, the preeminent political institution was the sovereign state. By consequence, debates on the nature and scope of justice focused almost exclusively on the protection of citizens' rights in their relationship to the state as well as their fellow citizens. Debates on the question of justice nevertheless changed drastically in the aftermath of World War II (WWII). The complex intertwinement of globalisation and decolonisation dynamics raised the question of the type of international order that could be conducive to the achievement of justice in inter-states relationships more particularly through making states directly accountable for violations of international law. ${ }^{1}$ Hence, the creation of the United Nations (UN) back in 1945 aimed to establish the conditions for the enhancement of justice at the national and international levels through the establishment of the International Court of Justice (ICJ); the development of international criminal justice; and the fight to alleviate poverty in a post-colonial era.

More than 70 years after the establishment of the UN, it is clear that global justice remains a non-achieved ideal and also a value under permanent threat. In 2017, the United Nations Security Council (UNSC) failed to refer the situation in Syria, 'the biggest humanitarian and refugee crisis of our time', ${ }^{2}$ to the jurisdiction of the International Criminal Court (ICC); the People's Republic of China (PRC) failed to recognise the legitimacy of the arbitral proceedings on the South China Sea (SCS) established by virtue of Annex VII of the United Nations Convention of the Law of the Sea (UNCLOS); a limited number of states recognise the ICJ's jurisdiction as compulsory; the use of words and the use of force still predominate in the recent assertive debates around the resolution of the North-Korean crisis; and individuals still very much lack effective remedies to control states' or transnational companies' actions and force them to comply with international law in general and international human rights law in particular.

Given China's importance as an international actor and the uncertain future of the existing international alliances system, it seems to be paramount to understand China's perspectives in order to account for the potential futures of global justice. This paper aims to contextualise China's own understanding of global justice in global governance. The paper will therefore not only uncover China's traditional understanding of justice and global justice as purveyors of order and stability, but also analyse the very pragmatic and instrumental Chinese views on the global institutional order that should be conducive to that ideal. This pragmatic and instrumental stance is very obvious in China's support for a restrictive understanding of the sovereignty concept; ambiguous

${ }^{1}$ For a detailed introduction to the notion of global justice see: Thomas Pogge, Global Justice (Hoboken: Blackwell, 2001), p. 258.; Ian Shapiro and Lea Brilmayer eds., Global Justice (New York: New York University Press, 1999), p. 222.

${ }^{2}$ UN High Commissioner for Refugees in United Nations, 'Syria conflict at 5 years: the biggest refugee and displacement crisis of our time demands a huge surge in solidarity', 15 March 2016, available at http://www.unhcr.org/afr/news/press/2016/3/56e6e3249/syria-conflict-5-years-biggest-refugeedisplacement-crisis-time-demands.html. 
support for a reform of the global governance architecture; and preference for nonbinding settlements to resolve international disputes. It will be demonstrated that China's approach to and appreciation of the SCS Arbitration is exemplary thereof.

This paper will be divided into three parts. In a first part, the paper introduces the concept of global justice and situates it in the broader context of global governance. In a second part, the paper describes the historical roots of China's own understanding of justice at the domestic and global level - a perspective that is characterised by a permanent search for order and stability. In a third part, the paper highlights China's own understanding of sovereignty, multi-polarity, and disputes resolution in order to grasp the nature of the global governance system under which China seeks to promote its own version of global justice. In a last part, this paper will argue that there is a momentum for the EU and China to further engage on the future reform of the global governance system and by extension secure avenues for the achievement of global justice.

\section{Global justice and governance in the $21^{\text {st }}$ century}

In the words of Andreas Follesdal and Thomas Pogge, 'The concept of global justice breaks down the traditional separation of intranational and international relations and extends institutional moral analysis to the whole field'. 3 The underlying idea of global justice is that some principles of justice do have a global reach and that the conditions of justice have also been globalised. ${ }^{4}$ The ideal of global justice should not be seen as an empty shell lacking any kind of substance. The drafters of the Universal Declaration of Human Rights (UDHR) indeed substantiated the ideal of global justice that should be protective of the rule of law, human rights, and democratic principles. Besides these fundamental constitutional values, matters such as the morality of war, the grounds of sovereignty, the permissibility of humanitarian interventions, migration, selfdetermination and poverty alleviation are also at the heart of global justice debates. 5 The very strong diversity of issues at stake explains why global justice debates have always had 'more or less no effect on real-world politics'. ${ }^{6}$

Central to the notion of global justice is the "causal impact of the design of the global institutional order upon the conditions under which human beings worldwide are living. ${ }^{7}$ Hence, the question of what kind of a global community (i.e. the institutional design of schemes of international cooperation) can provide the proper context for the

3 Andreas Follesdal and Thomas Pogge eds., Real World Justice (New York: Springer, 2005), p. 5.

4 Erik O. Eriksen, 'Three Conceptions of Global Political Justice', Globus Research Paper, 1/2016 (Oslo: ARENA), available at https://papers.ssrn.com/sol3/papers.cfm?abstract_id=2878745, p. 1.

5 Charles R. Beitz, 'Cosmopolitanism and Global Justice' in Gillian Brock and Darrel Moellendorf eds. Current Debates in Global Justice (New York: Springer, 2005), p. 27

${ }^{6}$ Chris Brown, 'Poverty Alleviation, Global Justice, and the Real World', Ethics \& International Affairs, vol. 31, no. 3, 2017, p. 359.

7 Andreas Follesdal and Thomas Pogge eds., Real World Justice (New York: Springer, 2005), p. 7. 
achievement of justice on a world scale is largely debated. ${ }^{8}$ In that context, the potential emergence of a 'community of law' 9 that would gradually supersede individual sovereignties and political loyalties remains very much uncertain.

It is arguable that the main challenges pertaining to the emergence of a 'community of law' that would serve the achievement of global justice directly relate to the very design of the global governance architecture as it has gradually developed since the termination of WWII. ${ }^{10}$ Hence, the horizontality, decentralisation, and weak institutionalisation of global governance explain the difficulty to guarantee the equality of all - individuals and states - before global justice; the absence of a legitimate source of global justice; and the enforcement shortcomings of justice at the global level. ${ }^{11}$

The horizontality of global governance refers to the fact that international relations and inter-states relations remain primarily centred around the principles of sovereign equality and non-interference enshrined in Article 2 of the UN Charter. ${ }^{12}$ This angular piece of the UN system has two implications. On the one side, it tends to hide the practical inequality that exists between states, which are 'born unequal' and 'destined to remain unequal'. ${ }^{13}$ In that sense, the theory of equality in international relations cannot hide the fact that 'all foreign relations in the past have involved degrees of equality shading into degrees of inequality'. ${ }^{14}$ On the other side, states rather than individuals, remain the premier subjects (and beneficiaries) of international law. In that context, the Responsibility to Protect ( $\mathrm{R} 2 \mathrm{P}$ ) doctrine is not likely to transform into a formal rule of international law in the years to come: "protective interventions remains both

\footnotetext{
8 Omar Dahbour, 'Three Models of Global Community', in Gillian Brock and Darrel Moellendorf eds. Current Debates in Global Justice (New York: Springer, 2005).

9 Ibid.

${ }^{10}$ The definition of global governance used in this paper is the one provided by the Commission on Global Governance: 'Governance is the sum of the many ways individuals and institutions, public and private, manage their common affairs. It is a continuing process through which conflicting or diverse interests may be accommodated and co-operative action may be taken. It includes formal institutions and regimes empowered to enforce compliance, as well as informal arrangements that people and institutions either have agreed to or perceive to be in their interest'. Commission on Global Governance, Our Global Neighbourhood - The Report of the Commission on Global Governance, Oxford University Press, 1995.

${ }^{11}$ This distinction is introduced in Matthieu Burnay, The Chinese Perspectives on the International Rule of Law: Law and Politics in the One-Party State (Cheltenham: Edward Elgar, forthcoming 2018).

${ }^{12}$ Article 2 of the UN Charter reads as follows: 'The Organization is based on the principle of the sovereign equality of all its Members [...] All Members shall refrain in their international relations from the threat or use of force against the territorial integrity or political independence of any state', UN, Charter of the United Nations, 1 U.N.T.S. XVI, signed in San-Francisco on 26 June 1945, effective on 24 October 1945, art. 2.

13 Robert W. Tucker, The Inequality of Nations (New York: Basic Books, 1977), p. 161.

14 Gungwu Wang, 'Early Ming Relations with Southeast Asia: A Background Essay', in John King Fairbank ed., The Chinese World Order: Traditional China's Foreign Relations (Cambridge: Harvard University Press, 1968), p. 61.
} 
institutionally complex and normatively contested in world order today'. ${ }^{15} \mathrm{R} 2 \mathrm{P}$ is a nonbinding doctrine, which emerged as an outcome of the 2005 UN World Summit and guarantees the international community's protection for citizens whose state fails to prevent them from suffering of genocidal practices, war crimes, and crimes against humanity. ${ }^{16}$ The current deadlock within the UNSC regarding the Syrian issue demonstrates, in fact, that sovereignty still institutes primarily an absolute right for the state to exercise its power over its territory in line with its own rules rather than a responsibility/a duty for the state to respect the basic rights of its citizens. This is the reality of the international order that remains primarily based upon political and power dynamics. ${ }^{17}$

The decentralisation of global governance testifies to the numerous sources of authority that should provide for the achievement of global public goods. The legitimacy shortcoming of global governance is partly explained by the underrepresentation of developing and emerging countries in key international proceedings. The world remains very much ruled by the West: 'Five hundred years of hegemony is not something likely to be undone in the space of a few years'. ${ }^{18}$ The failure to reform the UNSC acts here as a case in point that demonstrates the difficulty to reform the post-WWII international order in a way that would be more representative of the current balance of power. It can be argued that it is only by awarding sufficient attention to those 'voices from the outside'19 that a meaningful strengthening of the ideal of global justice will be made possible. In the existing international liberal order, global justice remains perceived as a product of western values and neo-colonialist policies. In this line, the African Union (AU) has repeatedly accused the ICC for unfairly targeting African leaders. The AU therefore decided to support its members who planned to withdraw from the ICC (e.g. Kenya) during the $2016 \mathrm{AU}$ summit in Addis Ababa. In the field of international criminal justice as in other global governance areas, 'the challenge is to provide a new and politically acceptable vocabulary for international engagement and transitional administration'.20

Finally, the weak institutionalisation of global governance is best explained by the elusive nature of international law that suffers from its lack of enforceability as well as from the proliferation of regulatory mechanisms (i.e. soft law, transnational law, private

15 Tim Dunne, 'The Responsibility to Protect and World Order' in Ramesh Thakur and William Maley eds., Theorising the Responsibility to Protect (Cambridge: Cambridge University Press, 2015), p. 81. ${ }_{16}$ UNGA, Resolution on the '2005 World Summit Outcome', A/RES/6o/1, 24 October 2005, para 138139.

${ }_{17}$ Jeremy Moses, Sovereignty and Responsibility: Power, Norms and Intervention in International Relations (Basingstoke: Palgrave Macmillan, 2014), p. 169.

${ }_{18}$ Michael Cox, 'Why the West Rules from Now', in David Held and Charles Roger eds., Global Governance at Risk (Cambridge: Polity Press, 2013), p. 126.

19 Summary of Remarks by Vikram Raghavan, 'Voices from the Outside: Sovereign Equality, International Law, and the Imbalance of Power', Proceedings of the Ninety-Ninth Annual Meeting of the American Society of International Law, vol. 99, 2005, p. 48.

${ }^{20}$ Ramesh Thakur, 'Conclusion: National Diplomacy and Global Governance', in Andrew F. Coopeter, Brian Hocking and William Maley eds., Global Governance and Diplomacy: Worlds Apart? (Basingstoke: Palgrave McMillan, 2008), p. 294. 
standards) at the global level. Despite the weak enforceability of most of the international/transnational regulatory instruments, 'those that breach them are held to account through their existence'. ${ }^{21}$ The question remains how the variety of existing instruments can be best coordinated in order for the multiplicity of actors (i.e. states, international organisations, multinational companies and civil society) involved in the regulatory process-making to meaningfully contribute to the ideal of global justice. Hence, 'global justice requires a permanent deliberation on the share of institutional responsibilities to be held to achieve it'. ${ }^{22}$

\section{Order and stability: A Chinese perspective on justice and global justice}

\section{Justice with Chinese characteristics}

There is a very wide literature that highlights the specificities of the Chinese legal tradition and its own understanding of justice. The contrast between the Western and Chinese understandings of justice can be illustrated simply by looking at the symbols that have been used to represent law and legality in both legal traditions. In Europe, law and legality has traditionally been symbolised by a reference to the goddess Justitia, a woman blindfolded who holds a measuring instrument. Law and legality in China has been symbolised by a unicorn-like mythical animal with a dragonhead, Xièzhì. On the one side, we have the continuous search for equilibrium and impartiality when imparting justice. ${ }^{23}$ On the other side, we have the affirmation of the non-temporal power to point at the wrong party or argument. ${ }^{24}$

In Imperial China, the traditional Chinese legal system found its philosophical foundations in the theories of Confucianism and Legalism. The dominant understanding of justice pointed to the development of a 'state-centred justice' with the Emperor acting as both the source and condition for the exercise of justice. ${ }^{25}$ At the very heart of China's traditional legal system laid a 'dissonance between high justice and low justice': the traditional legal system was grounded on the moral supremacy of the Emperor ('high

\footnotetext{
${ }^{21}$ Sophie Harman and David Williams, 'Conclusion: Governing the World', in Sophie Harman and David Williams eds., Governing the World? Cases in Global Governance (London: Routledge, 2013), p. 197.

${ }^{22}$ Allen Buchanan and Robert O. Keohane, 'The Legitimacy of Global Governance Institutions', Memo prepared for Conference on the Normative and Empirical Evaluation of Global Governance, Princeton University, 16-18 February 2006.

${ }^{23}$ Jacques de Ville, 'Mythology and the Images of Justice', Law and Literature, Vol. 23, No. 3, 2011, pp. 325-326.

24 Ibid.

25 Joshua Rosenzweig, 'State, Society and the Justice Debate in Contemporary China' in Flora Sapio, Susan Trevaskes, Sarah Biddulph, and Elisa Nesossi eds., Justice: The China Experience

(Cambridge: Cambridge University Press, 2017), p. 29.
} 
justice') and allocated a limited space to the fair treatment of individuals ('low justice'). ${ }^{26}$ Hence, law and legality functioned primarily as instruments for stability and order, and prioritised the value of punishment over justice. It is only at the end of the $19^{\text {th }}$ century and at the beginning of the $20^{\text {th }}$ century that China integrated new concepts into its own legal system and understanding of justice, such as those of subjective rights and constitutionalism. 'In a word, the law revision in the late Qing Dynasty was a proclamation to end the native Chinese legal history; in the end, the Chinese legal system was given way to the western legal civilization'.27

This historical heritage still marks the Chinese legal system in a certain way, as it has been developing since the beginning of the opening-up and reform policies at the end of the 1970's. At that time, Deng Xiaoping and his fellow reformists understood that the refoundation of the Chinese legal system was a necessary instrument to transform China into a more open society that would be attractive for foreign investments and conducive of economic growth. In that process, China has changed its own legal system from a very underdeveloped system to a sophisticated one, thanks to the enactment of numerous new laws as well as the strengthening of the state's legal and judicial capacity. ${ }^{28}$ Legal and judicial reforms have now come even more to the forefront of China's political agenda in the context of the 2014 Plenum of the Chinese Communist Party (CCP), which identified the transformation into a rule of law country as a strategic priority for the years to come. ${ }^{29}$ The reform process remains nevertheless (increasingly) constrained by the one party-rule of the CCP and the increasing gap between the law in the books and the actual reality of the Chinese legal system. ${ }^{30}$ The very uncertain and contradictory ways in which legal and judicial reforms have been implemented are good testimonies of China's current pragmatic and selective approach towards the value of justice. Benjamin Liebman talks about the 'law-stability paradox' to explain the necessary balancing exercise between the strengthening of the legal system and upholding order and stability. ${ }^{11}$ The strengthening of the Chinese legal system indeed constitutes a necessary instrument for the CCP to maintain its legitimacy as well as the political,

\footnotetext{
${ }^{26}$ Delia Lin, 'High Justice versus Low Justice: The Legacy of Confucian and Legalist Notions of Justice' in Flora Sapio, Susan Trevaskes, Sarah Biddulph, and Elisa Nesossi (eds.), Justice: The China Experience, Cambridge University Press, 2017, p. 89.

${ }_{27}$ Peng He, Chinese Law Making: From Non-Communicative to Communicative, (New York: Springer, 2014), p. IX.

${ }^{28}$ Matthieu Burnay, The Chinese Perspectives on the International Rule of Law: Law and Politics in the One-Party State, Edward Elgar, forthcoming 2018.

${ }_{29}$ Central Committee of the Chinese Communist Party, Fourth Plenum of the 18th Central Committee of the Chinese Communist Party Decision on 'Several Important Issues Regarding the All-Around Promotion of Ruling the State According to Law', 23 October 2014, available at http://genius.com/Central-committee-of-the-chinese-communist-party-decision-of-the-fourthplenum-of-the-18th-ccp-central-committee-english-annotated.

${ }^{30}$ Xiaobing Li and Qiang Fang, 'Legal Reforms in Twentieth-Century China', in Xiaobing Li and Qiang Fang eds., Modern Chinese Legal Reform: New Perspectives (Lexington: University Press of Kentucky, 2013), p. 1.

${ }^{31}$ Benjamin L. Liebman, 'Assessing China's Legal Reforms', Columbia Journal of Asian Law, Vol. 23, No. 1, 2009, p. 17.
} 
economic, and social stability of the state. Hence, the strengthening of the Chinese legal system and judicial independence can also prove to be a threat to the one-party rule. Concerns for the stability of the one-party rule clearly impede legal developments and judicial independence in certain areas of the Chinese legal system. ${ }^{32}$ The ongoing crackdowns in judicial circles 33 combined with the instrumentalisation of the legal system - including the 1982 Constitution - to strengthen the Party's power monopoly reinforces the perception of the recent 'authoritarian advance' in China. ${ }^{34}$

\section{Global justice with Chinese characteristics}

In order to situate the specificities of China's perspectives on global justice, it is useful to go back to the time of China's first encounters with international law. It was in the mid-19 ${ }^{\text {th }}$ Century that the Qing Dynasty was forced to face the negative implications of the successive military defeats against European states, the United-States and Japan and thereby entering into the family of nations. During that so-called 'century of humiliations', China was requested by force to sign a series of 'unequal treaties' that imposed the cession of parts of its territory, the application of extraterritoriality, as well as the payment of significant financial compensations. Sovereignty as a concept was completely foreign to the imperial tributary system and the Qing dynasty's own understanding of international affairs. China learned about the importance of sovereignty because of the international law instruments that third-states used to infringe its own sovereign rights. China arguably learned the rules of the game rapidly and attempted to use international law to its own advantage as early as the last years of the Qing Dynasty. In this respect, the Qing-Choson Treaty of 1882 was imposed by China upon Korea in order to contain the Japanese influence over the Korean peninsula. The treaty allowed for a greater interference of the Qing Dynasty into Korean domestic affairs and therefore constituted 'an attempt to turn Korea into a Western-style protectorate'. 35 The impact of the 'Century of Humiliations' should not be underestimated: 'the historical trauma of the unequal treaties with Western powers (1840-1945) has formed China as a nation-state'. ${ }^{36}$ It also explains, to a certain extent, the continuous emphasis on the importance of the concepts of sovereignty and non-intervention in China's practice of

${ }^{32}$ Scott Wilson, Tigers without Teeth: The Pursuit of Justice in Contemporary China (Lanham: Rowman and Littlefield, 2015), p. 220.

33 According to the Hong-Kong based NGO China Human Rights Lawyers Concern Group, it would be as many as 321 people (i.e. lawyers, law firms staff, and Human Rights activists) that have been affected by the ongoing repressive campaign.

34 Thorsten Benner, Jan Gaspers, Mareike Ohlberg, Lucrezia Poggetti, and Kristin Shi-Kupfer, 'Authoritarian Advance: Responding to China's Growing Influence in Europe', GPPI and merics report, February 2018, available at https://www.merics.org/sites/default/files/201802/GPPi MERICS Authoritarian Advance 2018 1.pdf.

35 Seo-Hyun Park, 'Changing Definitions of Sovereignty in Nineteenth-Century East Asia: Japan and Korea Between China and the West', Journal of East Asian Studies, Vol. 13, No. 2, 2013, p. 295.

${ }^{36}$ Sebastian Harnish, 'China's Historical Self and its International Role', in Sebastian Harnisch, Sebastien Bersick, and Jorn-Carsten Gottwald eds., China's International Roles (London: Routledge, 2016), p. 39. 
international law, as will be demonstrated below by an analysis of China's approach to the SCS arbitral proceedings.

Following the fall of the Qing Dynasty, the Republic of China (ROC) developed a very active foreign policy to ensure the abolition of unequal treaties and secure the protection of China's sovereignty rights. 37 At the time of the Republic, engagement with international law mainly aimed at addressing China's unequal treatment under international law. The ROC nevertheless also played a critical role in the development of a substantive idea of global justice enshrined in the Universal Declaration of Human Rights (UDHR). In fact, the ROC diplomat, Peng Chun Chang, acted as one of the main drafters of the UDHR together with Charles Malik of Lebanon, Eleonore Roosevelt of the United States, and René Cassin of France. In addition to the inclusion of the principle of 'conscience' to Article 1 of the UDHR,38 Peng Chun Chang helped render the Declaration truly universal by insisting on the need to take into account the cultural specificities of non-western parts of humanity while seeking to establish principles that could be agreeable to everyone. 39

When the PRC was established in 1949, China suffered from a significant isolation on the international stage. Due to a US blockage against PRC membership in the UN, the PRC was not recognised as a Permanent Member in the UNSC upon its creation: 'Excluded from the United Nations and, by its own strategy, without diplomatic relations even with the foreign powers that had recognized it, New China concentrated on its role as the revolutionary center in East Asia'.40 The PRC's first attempt to raise its international profile could be noticed from the early years of the Cold War when China bid to take the lead of the decolonising movement. In 1955, the PRC - represented by its Foreign Minister Zhu Enlai - played a key role in the Bandung Conference, which set the path for the Non-Aligned Movement (NAM) to be established in 1961. At the Bandung Conference, Third-World countries signified their intention to depart from the bipolar logic of the international system and to choose their own foreign policy paths. The Bandung Conference constitutes a landmark event in the construction of the PRC's own international identity. It highlighted the importance of sovereignty and multipolarity in China's foreign policy (infra): ${ }^{41}$ 'China's association with the Afro-Asian

\footnotetext{
${ }^{37}$ Soulié De Morant, Extraterritorialité et Intérets Etrangers en Chine (Paris: Librarie Orientaliste Paul Geuthner, 1925), p. 15.

${ }_{38}^{8}$ Pierre-Etienne Will, 'The Chinese Contribution to the Universal Declaration of Human Rights', in Mireille Delmas-Marty and Pierre-Etienne Will eds., China, Democracy, and Law: A Historical and Contemporary Approach (Leiden: Brill, 2012), p. 373.

39 Ibid., p. 374.

$4^{40}$ Odd Arne Westad, The Chinese Civil War: Decisive Encounters (Palo Alto: Stanford University Press, 2003), p. 316.

${ }^{41}$ The Ministry of Foreign Affairs, Republic of Indonesia , Final Communiqué of the Asian-African conference of Bandung, 24 April 1955, available at http://franke.uchicago.edu/ Final Communique Bandung 1955.pdf.
} 
group was deeply rooted in the faith of a non-hierarchical, non-western dominated world order in which China was ready to contribute as a constructive member'. ${ }^{42}$

The recognition of a permanent seat in the UNSC through Resolution 2758 of the UN General Assembly further helped China not to be isolated anymore. This regained international status did nevertheless not transform immediately into an activism in global affairs. Deng Xiaoping's political mantra to 'observe calmly, hold one's ground, respond soberly, and get some things done' did keep a strong hold on China's stance in global affairs in the course of the policies of opening and reforms under Deng Xiaoping, Jiang Zemin and Hu Jintao. This approach paid off as it was in the course of those years that China became an important stakeholders in most international organisations. The accession to the World Trade Organisation (WTO) constitutes probably the main 'landmark event'43 in China's re-emergence as a global power.

In all those years, it is fair to say that China's foreign policy purpose has not been to overthrow the international institutions and principles in place: 'China has now concluded over 23,000 bilateral treaties with other countries, signed more than 400 multilateral agreements, and joined the majority of the major inter-governmental organizations of the world as well as many international non-governmental organisations'. ${ }^{44}$ From an institutional perspective, China did not act as a driving force for change and largely confirmed the design of the global institutional order characterised by its uneven contribution to the ideal of global justice. From a substantial perspective, China's selective socialisation - as best exemplified by its reluctant engagement and compliance with international human rights norms 45 - did not challenge the fundamental underpinnings of the international legal order. The extension of the principle of justice to inter-states relations was primarily perceived by China as a way to enhance stability and order at the national, regional, and international level.

Very far from Deng Xiaoping's motto of 'keeping a low profile', China has now emerged as an active stakeholder in global governance under the Presidency of Xi Jinping. The policy adage that underpinned most of China's foreign policies in the opening-up and reforms era has, in fact, largely been abandoned. It has been replaced by the strategy of 'striving for achievement' as outlined in a speech by President Xi Jinping at the foreign affairs conference of the CCP on 24 October 2013. ${ }^{6}$ The strategy of 'striving for achievement' has conducted China to gradually become a rule shaper, not to say a rule

42 Yifeng Chen, 'Bandung, China, and the Making of World Order in East Asia' in Luis Eslava, Michael Fakhri, Vasuki Nesiah eds., Bandung, Global History, and International Law Critical Pasts and Pending Futures (Cambridge: Cambridge University Press, 2017), p. 192.

43 Xiaohui Wu, 'No Longer Outside, Not Yet Equal: Rethinking China's Membership in the World Trade Organization', Chinese Journal of International Law, Vol 10., No. 2, 2011, p. 228.

44 Gerald Chan, 'China and Global Governance: Evolving Approaches', in Hoo Tiang Boon ed., Chinese Foreign Policy under Xi (London: Routledge, 2017), p. 162.

45 See Bjorn Ahl, 'The Rise of China and International Human Rights Law', Human Rights Quarterly, Vol. 37, 2015.

${ }^{46}$ Xuetong Yan, 'From Keeping a Low Profile to Striving for Achievement', The Chinese Journal of International Politics, Vol. 7, No. 2, 2014, p. 154. 
maker in global governance. In that process, China has attempted to enhance its foreign policy discursive power internally and externally. China's commitment to 'building a community with a shared future for mankind', expressed at the occasion of the 19th National Congress of the Communist Party of China (CPC National Congress) should allegedly provide peace, contribute to global development and uphold the international order. 47 These increased contributions to global public goods should provide the necessary environment for upholding the 'China's national rejuvenation' by the time of the hundredth anniversary of the creation of the PRC in 2049. ${ }^{8}$ In practice, it nevertheless remains to be seen how China will transform its claims to 'uphold international fairness and justice' by taking 'an active part in reforming and developing the global governance system, and keep contributing Chinese wisdom and strength to global governance' 49 into actual policies.

\section{China's contribution to global justice: Sovereignty, multi-polarity, and international adjudication}

In order to understand China's contribution to global justice, it is necessary to take due account of China's own understanding of sovereignty; its selective approach towards multi-polarity; as well as its preference for non-binding dispute settlement mechanisms.

As mentioned above, it is since the very early phases of China's involvement in the postWWII international system that China put the principles of sovereignty and nonintervention at the very heart of its foreign policy. In this line, President Xi Jinping reiterated at the occasion of the $60^{\text {th }}$ anniversary of the Bandung Conference that

'[a]ll countries should exercise their rights in accordance with the law, oppose bending international law, and reject any attempt to undermine, in the name of "rule of law", other countries' legitimate rights and interests as well as peace and stability'.50

China's emphasis on the principles of sovereignty and non-intervention still acts as the main impediment against the development of the ideal of global justice. The emphasis

${ }^{47}$ Jinping Xi, 'Secure a Decisive Victory in Building a Moderately Prosperous Society in All Respects and Strive for the Great Success of Socialism with Chinese Characteristics for a New Era', 18 October 2017, 21-22, available at http://www.xinhuanet.com/english/download/Xi Jinping\%27s report at 19th_CPC National_Congress.pdf.

48 Xuetong Yan, 'From Keeping a Low Profile to Striving for Achievement', The Chinese Journal of International Politics, Vol. 7, No. 2, 2014, p.166.

49 Jinping Xi, 'Secure a Decisive Victory in Building a Moderately Prosperous Society in All Respects and Strive for the Great Success of Socialism with Chinese Characteristics for a New Era', 18 October 2017, 53-54, available at http://www.xinhuanet.com/english/download/Xi_Jinping\%27s_report at 19th CPC National Congress.pdf.

$5^{\circ}$ Address by H.E. Mr. Xi Jinping President of the People's Republic of China at Meeting Marking the 6oth Anniversary Of the Initiation of the Five Principles of Peaceful Coexistence, 28 June 2014, available at http://www.china.org.cn/world/2014-07/07/content 32876905.htm 
on sovereignty is in this line very often used as a legitimising factor for China's vetoes in the UNSC. One can think for instance of the vetoes on resolutions condemning human rights violations in Myanmar (2008)51 or Zimbabwe (2007)..$^{52}$ One can also think of the six successive vetoes China cast together with Russia on resolutions targeting the situation in Syria. This included a veto against UNSC Draft Resolution 348 (2014) that aimed to refer the situation in Syria to the jurisdiction of the ICC.53 It is not to say that China has never proved to be flexible regarding the sovereignty and non-intervention principles. China for instance voted in favour of UNSC Resolution 1970 (2011) ${ }^{54}$ that referred the situation in Libya to the jurisdiction of the ICC and voted in favour of UNSC Resolution 1542 (2004)55 on the situation in Haiti despite the country's disregard for the One China principle. In the area of international criminal justice, China has also interestingly never blocked the establishment of ad hoc international criminal tribunals. For instance, China supported the establishment of the International Criminal Tribunal for the former Yugoslavia (ICTY) ${ }^{56}$ and the International Criminal Tribunal for Rwanda (ICTR). 57 China has in that process always emphasised the principle of complementarity of international tribunals to domestic courts. 58

A second key challenge to the development of global justice relates to the lack of legitimacy of global governance. China's contribution to enhance the legitimacy of global governance is characterised by a significant gap between what China could potentially contribute to when it comes to reforms and what China actually does in practice. China's diplomacy allegedly aims to shape the US unipolar moment and supports a shift in the global balance of power towards multi-polarity. ${ }^{59}$ In this respect, China has for instance always been keen to affirm that the very foundations of its strategic partnership with the European Union (EU) are anchored in such a multi-polar strategic framework. ${ }^{60}$ China has also been a very strong advocate of reforming the governance of the International Monetary Fund (IMF) and the World Bank: two institutions that should be reformed to 'reflect changes in the international landscape'. ${ }^{61}$ Due to China's pressure to reform the IMF, an ambitious reform package was adopted in 2010. This reform package took more

${ }^{11}$ UNSC Draft Resolution S/2007/14 - 12/01/2007.

${ }^{2}$ UNSC Draft Resolution S/2008/447 - 11/07/2008.

53 UNSC Draft Resolution S/2014/348, 22 May 2014.

54 UNSC Resolution S/RES/1970, 26 February 2011.

55 UNSC Resolution S/RES/1542, 30 April 2004.

${ }^{56}$ UNSC Resolution S/RES/827, 25 May 1993.

57 UNSC Resolution S/RES/955, 8 November 1994.

${ }^{8}$ Lijun Yang, 'On the Principle of Complementarity in the Rome Statute of the International Criminal Court', Chinese Journal of International Law, Vol. 4, No. 1, 2005, p. 130.

59 Gregory Chin, 'China's Rising Institutional Influence', in Alan S. Alexandroff and Andrew F. Cooper eds, Rising States, Rising Institutions (Washington DC: Brookings Institution Press, 2010), p. 85.

${ }^{60}$ Tao Song, 'Creating a Bright Future for China-EU Relations Based on Achievement and Success', China Institute of International Studies, 31 December 2012, available at http://www.ciis.org.cn/english/2012-12/31/content_5638039.htm.

${ }^{61}$ X., 'Xi Stresses Urgency of Reforming Global Governance', Xinhua News, 13 October 2015, available at http://news.xinhuanet.com/english/2015-10/13/c 134710464.htm. 
than five years to be approved and to enter into force due to the blockage in the United States Congress. In practice, China has nevertheless been accused of 'seeking global multi-polarity but regional uni-polarity'. ${ }^{62}$ The best example of this selective approach toward multi-polarity can be found in China's passivity to encourage the UNSC's reform agenda. China has in this line never openly supported the claims of some of its main regional competitors - India and Japan - to become Permanent Members of the UNSC.

Whereas it has been argued above that China's selective socialisation has thus far not challenged the fundamental underpinnings of the international legal system, further socialisation will be necessary if China wants to pursue its strategy of 'striving for achievement' to create a 'shared future for mankind with mutually beneficial outcomes'. The July 2016 South China Sea (SCS) Arbitration remarkably - and seemingly somewhat contradictory - serves as an excellent example of China's socialisation with international law and adjudication on the one hand, but strong emphasis on sovereignty and preference for non-binding dispute settlement in international relations, illustrating the limited nature of this socialisation, on the other.

From the very moment the Philippines notified China of its request for the establishment of an Arbitral Tribunal with the Permanent Court of Arbitration, China consistently held that it would 'neither accept nor participate in the arbitration'. ${ }^{63}$ On the other hand, even though China consistently ignored requests for information, documentation and proof by the arbitral tribunal, China did in its very own 'non-participatory' way participate in the proceedings by regularly issuing statements and position papers on the proceedings. ${ }^{64}$ China's approach to the SCS Arbitration has been one focusing not so much on the merits of the case; rather China chose to challenge the jurisdiction of the arbitral tribunal, albeit not through the designated procedural mechanisms. In its Position Paper on the Matter of Jurisdiction in the South China Sea Arbitration, China, inter alia, emphasised that China and the Philippines have agreed 'to settle their relevant disputes through negotiations'. ${ }^{65}$ China refers in this respect to several joint statements and the 2002 Declaration on the Conduct of the Parties in the South China Sea (DOC); all remarkably non-binding instruments. According to the Position Paper ' $[\mathrm{b}] \mathrm{y}$ repeatedly reaffirming negotiations as the means for settling relevant disputes, and by emphasising that negotiations be conducted by sovereign States directly concerned,

\footnotetext{
${ }^{62}$ Amitav Acharya, 'Can Asia lead? Power Ambitions and Global Governance in the Twenty-First Century', International Affairs, Vol. 87, No. 4, 2011, p. 867.

${ }^{63}$ Ministry of Foreign Affairs of the People's Republic of China, 'Position Paper of the Government of the PRC on the Matter of Jurisdiction in the South China Sea Arbitration Initiated by the Republic of the Philippines', 7 December 2014, available at http://www.fmprc.gov.cn/nanhai/eng/snhwtlcwj_1/ t1368895.htm.

64 Wim Muller, 'A Return to the Rule of Law in the South China Sea?', Chatham House, 11 November 2015, available at https://www.chathamhouse.org/expert/comment/return-rule-law-south-chinasea.

${ }^{65}$ Ministry of Foreign Affairs of the People's Republic of China, 'Position Paper of the Government of the PRC on the Matter of Jurisdiction in the South China Sea Arbitration Initiated by the Republic of the Philippines', 7 December 2014, available at http://www.fmprc.gov.cn/nanhai/eng/snhwtlcwj 1/ t1368895.htm.
} 
the above-quoted provisions of the bilateral instruments and [...] the DOC obviously have produced the effect of excluding any means of third-party settlement'. ${ }^{66}$ Hence, China concluded: 'with regard to all the disputes between China and the Philippines in the South China Sea, including the Philippines' claims in this arbitration, the only means of settlement as agreed by the two sides is negotiations, to the exclusion of any other means'. ${ }^{67}$ Interestingly, and despite its strong rejection of the (jurisdiction of the) arbitral tribunal, China relied on international law, including international law in general, as well as the UNCLOS and ICJ case-law to substantiate their stance. Prima facie this seems to bear testimony to China's socialisation with the international legal system, including with the jurisprudence of international courts and tribunals. However, China's subsequent attitude towards the proceedings and more particularly the fact that it forfeited its right under UNLOS Annex VII to appoint - and hence influence the outcome of the proceedings - at least one arbitrator, who could even be a Chinese national, testifies to a very limited socialisation with this kind of proceedings and subject matters. In the course of the further proceedings and even after the arbitral tribunal had established its jurisdiction and issued its award on the merits, China consistently emphasised its adherence to settle the South China Sea issue through bilateral negotiations in its statements. Hence, it came as no real surprise that in its statement issued the day the award on the merits were rendered, China upheld its initial stance of not accepting the decision, declaring it 'null and void'. ${ }^{68}$ In a second statement, China once again placed emphasis on settling the dispute through negotiation and in that regard referred to the Five Principles of Peaceful Coexistence, as established at the Bandung Conference and of which sovereignty and non-intervention are the two cardinal notions. ${ }^{69}$

In order to put its money where its mouth is, China together with the ASEAN Foreign Ministers, agreed on a Framework for a Code of Conduct (COC) in the South China Sea at the August 2017 ASEAN Foreign Ministers Meeting. The content of this framework has not been published and whereas this should be a step forward from the 2002 nonbinding DOC towards a binding instrument to manage and settle the SCS disputes, commentators fear, based on leaked drafts of the text, that a potential COC will again be non-binding, without dispute settlement and enforcement mechanisms.

The South China Sea Arbitration demonstrates that China's socialisation with international adjudication, at least in this field, is still very limited and tainted by its vision

\footnotetext{
66 ibid.

67 ibid.

68 Ministry of Foreign Affairs of the People's Republic of China, 'Statement of the Ministry of Foreign Affairs of the People's Republic of China on the Award of 12 July 2016 of the Arbitral Tribunal in the South China Sea Arbitration Established at the Request of the Republic of the Philippines', 12 July 2012, available at http://www.fmprc.gov.cn/nanhai/eng/snhwtlcwj 1/t1379492.htm.

69 Ministry of Foreign Affairs of the People's Republic of China, 'China Adheres to the Position of Settling Through Negotiation the Relevant Disputes Between China and the Philippines in the South China Sea', 13 July 2016, available at http://www.fmprc.gov.cn/nanhai/eng/snhwtlcwj 1/ t1380615.htm.
} 
on and strong adherence to sovereignty, non-interference and the subsequent preference for non-binding dispute settlement through negotiations. However, China has demonstrated a very successful socialisation with international adjudication in other fields. China's development from a patient learner to an active player in the WTO Dispute Settlement Mechanism (DSM) is the prime example thereof and stands in sharp contrast to its lack of socialisation in other fields of international binding dispute settlement. Since its accession to the WTO in 2001, China has become one of the most active users - both as plaintiff and respondent - of the WTO DSM, filing cases against big players such as the EU and the United States.70

\section{A momentum for the EU to engage with China in the search for global justice}

It is fair to say that China presents both a challenge and an opportunity for the development of global justice, more particularly from the perspective of the European Union (EU). China's peculiar attitude towards sovereignty, multi-polarity and international adjudication, as analysed above, does not necessarily obstruct the further enhancement and development of global justice all together, nor does it hamper or limit a prominent Chinese role therein. Whereas many warn about the danger of global justice leading to the creation of a super-state that cannot be stopped or constrained by other states, Gosepath argues that global justice is compatible with a system of dispersed political sovereignty..$^{71}$ Given that the institutions themselves adhere to the basic global principles of justly institutionalised organisations, global justice can allow for a plurality and diversity of cultures, traditions and comprehensive doctrines compatible with the universalistic egalitarian principles of justice. ${ }^{72}$ Hence, we should not $a b$ initio shy away from or distrust a potential significant contribution by China to the enhancement of global justice. In a changing world where China has claimed to become one of the main frontrunners of multilateralism, 73 we argue that there is a real momentum for the EU to further engage with China in support of the strengthening of global justice. Recently, Chinese Foreign Minister Wang Yi pointed out that global justice is one of the core principles to foster this new form of international relations of which China sees itself as

\footnotetext{
${ }^{70}$ See Matthieu Burnay and Jan Wouters, 'The EU and China in the WTO: What Contribution to the International Rule of Law? - Reflections in Light of the Raw Materials and Rare Earths Disputes', in Jianwei Wang and Weiqing Song eds., China, the European Union, and International Politics of Global Governance (Basingstoke: Palgrave MacMillan, 2016), p. 118. See also, Jan Wouters and Matthieu Burnay, 'China and the European Union in the World Trade Organization: Living Apart Together?', in Jan Wouters, Tanguy de Wilde, Pierre Defraigne and Jean-Christophe Defraigne eds., China, the European Union and the Restructuring of Global Governance (Cheltenham: Edward Elgar, 2012).

${ }^{71}$ Stefan Gosepath, 'The Global Scope of Justice', Metaphilosophy, Vol. 32, No. 1/2, 2001, p. 152.

72 ibid.

73 World Economic Forum, 'President Xi's Speech to Davos', 17 January 2017, available at https://www.weforum.org/agenda/2017/01/full-text-of-xi-jinping-keynote-at-the-world-economicforum.
} 
the main driving force: 'The law of the jungle which puts the weak at the mercy of the strong must be rejected, and the legitimate rights and interests of all countries, in particular developing countries, should be upheld'.74

In practice, China has developed a certain degree of flexibility regarding sovereignty and non-intervention despite these two principles being deeply and fundamentally embedded in China's foreign policy tradition. This flexibility is likely to become even more necessary in a context where China increasingly projects its own interests abroad in the context of the Belt and Road Initiative. The Belt and Road initiative will not only bolster China's soft power 75 but it will also strengthen China's interdependence and need for dialogue with its close and far neighbourhood. In addition, China presents a discourse that aims to fundamentally re-invent the structure of global governance. In a context where we can see a resurgence of a US isolationist foreign policy, there is a clear 'window of opportunity' for China to do so. ${ }^{76}$ Whether China's proclaimed commitment to make the global structure more democratic and representative of the interests of emerging powers materialises into concrete actions remains to be seen. Lastly, China's progressive and selective socialisation with international law and adjudication demonstrates that China does not aim to overthrow the international liberal order as it was established after the termination of WWII. However, the question remains how China's selective and pragmatic approach towards international law and adjudication can be reconciled with established international rules and principles.

In order for this momentum to materialise and as we have seen in this paper, socialisation remains key for China's contribution to global justice. The experience of the WTO demonstrates that despite the very constraining nature of international trade law, China has proved to act as a fair player in the context of the WTO DSM. The EU should therefore urge China to be more reactive - not to say proactive -regarding other areas of global governance that contribute to the enhancement of global justice. One could think for instance of encouraging China to improve the quality and extent of its participation' to the debates of the International Law Commission, which still very much form the backbone of the reflections on the future developments of the international liberal order. 77 In addition, the EU should engage with China much more in the areas that have become key priorities in the Chinese foreign policy, such as the whole debate

\footnotetext{
74 Ministry of Foreign Affairs of the People's Republic of China, 'Speech by Foreign Minister Wang Yi at the Opening of the Symposium on International Developments and China's Diplomacy in 2017 ', 10 December 2017, available at http://www.fmprc.gov.cn/mfa eng/wjbxw/t1518130.shtml.

75 Angie Cui, 'Building the Belt and Road: The Overlooked Unveiling of China's Boldest', Harvard International Review, Vol. 39, 2018, p. 16.

${ }^{76}$ Astrid H. M. Nordin and Mikael Weissmann, 'Will Trump Make China Great Again? The Belt and Road Initiative and International Order', International Affairs, Vol. 94, 2018, p. 244.

77 Jie Song, 'Evaluating the Effectiveness of China's Participation in International Legal Matters: Lessons from China's Practice in the International Law Commission and the International Court of Justice', China: An International Journal, Vol. 15, No. 2, 2017, p. 144.
} 
around global commons (e.g. Artic policy, space policy). ${ }^{8}$ It is in the common interests of both China and the EU to further engage in those debates and take them to the next level. These debates and the resulting cooperation should be based on reciprocity and adherence to their respective international obligations.

\section{Conclusions}

Both at the World Economic Forum in Davos and more recently at the $19^{\text {th }}$ CPC National Congress Xi Jinping proclaimed an enhanced Chinese commitment to global governance 'with Chinese characteristics', albeit just as the domestic model for future political and institutional development. 79 The analysis made in this paper emphasised China's general approach towards sovereignty, the reform of the existing global governance architecture, and international adjudication. The different arguments highlighted the ideal design of the global institutional order from a Chinese perspective, which, if successful may result in 'a new form of international relations' ${ }^{80}$ It is in that context that one should consider the potential contribution of China to the enhancement of global justice. This contribution will ultimately be shaped by China's own experience with international law as it has gradually evolved since the $19^{\text {th }}$ century as well as in view of the latest developments within the Chinese legal system. This paper demonstrated that the Chinese perspective on justice and global justice remains primarily determined by a constant search for order and stability.

This paper argued that the rest of the global community should not ab initio shy away from the Chinese perspectives on sovereignty, the reform of the existing global governance architecture, and international adjudication. With the ideal of global justice being far from achieved in the $21^{\text {st }}$ century and being challenged on a daily basis, a fresh wind in the approach to global governance is perhaps very welcome. Hence, this paper has argued that there is a momentum, particularly for the EU, to engage with China when it comes to reforming the global governance system and thereby getting one step closer to a global institutional order conducive to global justice.

One should nevertheless not be naïve and it is therefore with the deepest concerns that one should refer to the recent 'authoritarian advance' in China. The recent constitutional amendments reemphasising the central role played by the Party over the executive,

\footnotetext{
${ }^{78}$ See for instance the recent release of a white paper on China's Artic Policy: Jichang Lulu, 'China's Arctic Policy', China Policy Institute, 12 February 2018, available at https://cpianalysis.org/2018/ 02/12/icy-xi-speak-and-northerly-exoprop-the-arctic-white-paper/.

79 World Economic Forum, World Economic Forum, 'President Xi's Speech to Davos', 17 January 2017, available at https://www.weforum.org/agenda/2017/01/full-text-of-xi-jinping-keynote-atthe-world-economic-forum.

80 Ministry of Foreign Affairs of the People's Republic of China, 'Speech by Foreign Minister Wang Yi at the Opening of the Symposium on International Developments and China's Diplomacy in 2017 ', 10 December 2017, available at http://www.fmprc.gov.cn/mfa eng/wjbxw/t1518130.shtml.
} 
legislative and judicial power; ${ }^{81}$ the ongoing crackdown against human rights activist known as the 709 crackdown; 82 the revival of re-education through labour in the Xinjiang region ${ }^{83}$ are all recent political developments that testify to the fact that the genuine nature of China's commitment to an ideal of justice at home remains deeply uncertain. The contribution of China to the emergence of a more egalitarian ideal of justice at the global level is therefore likely to be very much dependent upon the future domestic policy and normative choices made by China.

\footnotetext{
${ }^{81}$ Kerry Brown, 'China's Lucky Leader Wins Again: The Secrets of Xi Jinping's Success', Newstatesman, 2 March 2018, available at https://www.newstatesman.com/world/2018/03/chinas-lucky-leader-wins-again-secrets-xi-jinping-s-success.

${ }^{82}$ Hualing Fu, 'The July 9th (709) Crackdown on Human Rights Lawyers: Legal Advocacy in an Authoritarian State', Journal of Contemporary China, Vol. 27, No 112, 2018.

83 Jerome A. Cohen, 'China Is Likely to Enter another Long Period of Severe Dictatorship', 26 February 2018, available at http://www.jeromecohen.net/jerrys-blog/china-is-likely-to-enteranother-long-period-of-severe-dictatorship.
} 


\section{References}

\section{Primary sources}

'Address by H.E. Mr. Xi Jinping President of the People's Republic of China At Meeting Marking the 6oth Anniversary Of the Initiation of the Five Principles of Peaceful Coexistence', 28 June 2014, available at http://www.china.org.cn/world/201407/07/content 32876905.htm.

Central Committee of the Chinese Communist Party, 'Fourth Plenum of the 18th Central Committee of the Chinese Communist Party Decision on 'Several Important Issues Regarding the All-Around Promotion of Ruling the State According to Law', 23 October 2014, available at http://genius.com/Central-committee-of-the-chinesecommunist-party-decision-of-the-fourth-plenum-of-the-18th-ccp-centralcommittee-english-annotated.

Charter of the United Nations, 1 U.N.T.S. XVI, signed in San-Francisco on 26 June 1945.

The Ministry of Foreign Affairs, Republic of Indonesia, Final Communiqué of the AsianAfrican conference of Bandung, 24 April 1955, available at http://franke.uchicago.edu/Final Communique Bandung 1955.pdf.

Ministry of Foreign Affairs of the People's Republic of China, 'Statement of the Ministry of Foreign Affairs of the People's Republic of China on the Award of 12 July 2016 of the Arbitral Tribunal in the South China Sea Arbitration Established at the Request of the Republic of the Philippines', 12 July 2012, available at http://www.fmprc.gov.cn/nanhai/eng/snhwtlcwj 1/t1379492.htm.

Ministry of Foreign Affairs of the People's Republic of China, 'Position Paper of the Government of the PRC on the Matter of Jurisdiction in the South China Sea Arbitration Initiated by the Republic of the Philippines', 7 December 2014, available at http://www.fmprc.gov.cn/nanhai/eng/snhwtlcwj 1/t1368895.htm.

Ministry of Foreign Affairs of the People's Republic of China, 'China Adheres to the Position of Settling Through Negotiation the Relevant Disputes Between China and the Philippines in the South China Sea', 13 July 2016, available at http://www.fmprc.gov.cn/nanhai/eng/snhwtlcwj 1/t1380615.htm.

Ministry of Foreign Affairs of the People's Republic of China, 'Speech by Foreign Minister Wang Yi at the Opening of the Symposium on International Developments and China's Diplomacy in 2017,, 10 December 2017, available at http://www.fmprc.gov.cn/mfa eng/wjbxw/t1518130.shtml.

World Economic Forum, 'President Xi’s Speech to Davos', 17 January 2017, available at https://www.weforum.org/agenda/2017/01/full-text-of-xi-jinping-keynote-at-theworld-economic-forum.

UNGA, Resolution on the '2005 World Summit Outcome', A/RES/6o/1, 24 October 2005 . 
UN High Commissioner for Refugees in United Nations, 'Syria conflict at 5 years: the biggest refugee and displacement crisis of our time demands a huge surge in solidarity', 15 March 2016, available at http://www.unhcr.org/afr/news Lpress/2016/3/56e6e3249/syria-conflict-5-years-biggest-refugee-displacementcrisis-time-demands.html.

UNSC Draft Resolution S/2007/14, 12 January 2007.

UNSC Draft Resolution S/2008/447, 11 July 2008.

UNSC Draft Resolution S/2014/348, 22 May 2014.

UNSC Resolution S/RES/1970, 26 February 2011.

UNSC Resolution S/RES/1542, 30 April 2004.

UNSC Resolution S/RES/827, 25 May 1993.

UNSC Resolution S/RES/955, 8 November 1994.

Jinping Xi, 'Secure a Decisive Victory in Building a Moderately Prosperous Society in All Respects and Strive for the Great Success of Socialism with Chinese Characteristics for a New Era', 18 October 2017, 21-22, available at http://www.xinhuanet.com/ english/download/Xi Jinping\%27s report at 19th CPC National Congress.pdf.

\section{Secondary sources}

Amitav Acharya, 'Can Asia lead? Power Ambitions and Global Governance in the Twenty-First Century', International Affairs, Vol. 87, No. 4, 2011.

Bjorn Ahl, 'The Rise of China and International Human Rights Law', Human Rights Quarterly, Vol. 37, 2015.

Charles R. Beitz, 'Cosmopolitanism and Global Justice' in Gillian Brock and Darrel Moellendorf eds., Current Debates in Global Justice (New York: Springer, 2005).

Thorsten Benner, Jan Gaspers, Mareike Ohlberg, Lucrezia Poggetti, and Kristin ShiKupfer, 'Authoritarian Advance: Responding to China's Growing Influence in Europe', February 2018, available at https://www.merics.org/sites/default/files/201802/GPPi MERICS Authoritarian Advance 2018 1.pdf.

Hoo Tiang Boon, 'Xi Jinping's Calibration of Chinese Foreign Policy', in Hoo Tiang Boon ed., Chinese Foreign Policy under Xi, (London: Routledge, 2017).

Chris Brown, 'Poverty Alleviation, Global Justice, and the Real World', Ethics \& International Affairs, Vol. 31, 2017.

Kerry Brown, 'China's Lucky Leader Wins Again: The Secrets of Xi Jinping's Success', Newstatesman, 2 March 2018, available at https://www.newstatesman.com/world 2018/03/china-s-lucky-leader-wins-again-secrets-xi-jinping-s-success.

Allen Buchanan and Robert O. Keohane, 'The Legitimacy of Global Governance Institutions', Memo prepared for Conference on the Normative and Empirical Evaluation of Global Governance, Princeton University, 16-18 February 2006.

Matthieu Burnay, The Chinese Perspectives on the Rule of Law and the International Rule of Law: Law and Politics in the One-Party State, (Cheltenham: Edward Elgar, forthcoming). 
Matthieu Burnay and Jan Wouters, 'The EU and China in the WTO: What Contribution to the International Rule of Law? - Reflections in Light of the Raw Materials and Rare Earths Disputes', in Jianwei Wang and Weiqing Song eds., China, the European Union, and the International Politics of Global Governance (Basingstoke: Palgrave MacMillan, 2016).

Gerald Chan, 'China and Global Governance: Evolving Approaches', in Hoo Tiang Boon ed., Chinese Foreign Policy under Xi (London: Routledge, 2017).

Yifeng Chen, 'Bandung, China, and the Making of World Order in East Asia' in Luis Eslava, Michael Fakhri and Vasuki Nesiah eds., Bandung, Global History, and International Law Critical Pasts and Pending Futures (Cambridge: Cambridge University Press, 2017).

Gregory Chin, 'China's Rising Institutional Influence', in Alan S. Alexandroff and Andrew F. Cooper eds., Rising States, Rising Institutions (Washington DC: Brookings Institution Press, 2010).

Jerome A. Cohen, 'China Is Likely to Enter another Long Period of Severe Dictatorship', 26 February 2018, available at http://www.jeromecohen.net/jerrys-blog/china-islikely-to-enter-another-long-period-of-severe-dictatorship.

Commission on Global Governance, Our Global Neighbourhood - The Report of the Commission on Global Governance (Oxford: Oxford University Press, 1995).

Michael Cox, 'Why the West Rules from Now', in David Held and Charles Roger eds., Global Governance at Risk (Cambridge: Polity, 2013).

Angie Cui, 'Building the Belt and Road: The Overlooked Unveiling of China's Boldest', Harvard International Review, Vol. 39, 2018,

Omar Dahbour, 'Three Models of Global Community', in Gillian Brock and Darrel Moellendorf eds., Current Debates in Global Justice (New York: Springer, 2005).

Soulié De Morant, Extraterritorialité et Intérets Etrangers en Chine (Paris: Librarie Orientaliste Paul Geuthner, 1925).

Jacques de Ville, 'Mythology and the Images of Justice', Law and Literature, Vol. 25, No. 3, 2011.

Tim Dunne, 'The Responsibility to Protect and World Order' in Ramesh Thakur and William Maley eds., Theorising the Responsibility to Protect (Cambridge: Cambridge University Press, 2015).

Erik O. Eriksen, 'Three Conceptions of Global Political Justice', Globus Research Paper, 1/2016, (Oslo: ARENA), available at https://papers.ssrn.com/sol3/ papers.cfm?abstract $\mathrm{id}=\mathbf{2 8 7 8 7 4 5}$.

Andreas Follesdal and Thomas Pogge eds., Real World Justice (New York: Springer, 2005).

Stefan Gosepath, 'The Global Scope of Justice', Metaphilosophy, Vol. 32, No. 1/2, 2001.

Sophie Harman and David Williams, 'Conclusion: Governing the World', in Sophie Harman and David Williams eds., Governing the World? Cases in Global Governance (London: Routledge, 2013). 
Sebastian Harnish, 'China's Historical Self and its International Role', in Sebastian Harnisch, Sebastien Bersick, and Jorn-Carsten Gottwald eds., China's International Roles (London: Routledge, 2016).

Peng He, Chinese Law Making: From Non-Communicative to Communicative, (New York: Springer, 2014).

Hualing Fu, 'The July 9th (709) Crackdown on Human Rights Lawyers: Legal Advocacy in an Authoritarian State', Journal of Contemporary China, Vol. 27, No. 112, 2018.

Xiaobing Li and Qiang Fang, 'Legal Reforms in Twentieth-Century China', in Xiaobing Li and Qiang Fang eds., Modern Chinese Legal Reform: New Perspectives (Lexington: University Press of Kentucky, 2013).

Benjamin L. Liebman, 'Assessing China's Legal Reforms', Columbia Journal of Asian Law, Vol. 23, No. 1, 2009.

Delia Lin, 'High Justice versus Low Justice: The Legacy of Confucian and Legalist Notions of Justice' in Flora Sapio, Susan Trevaskes, Sarah Biddulph, and Elisa Nesossi eds., Justice: The China Experience (Cambridge: Cambridge University Press, 2017).

Jichang Lulu, 'China’s Arctic Policy', China Policy Institute, 12 February 2018, available at https://cpianalysis.org/2018/02/12/icy-xi-speak-and-northerly-exoprop-thearctic-white-paper/.

Jeremy Moses, Sovereignty and Responsibility: Power, Norms and Intervention in International Relations (Basingstoke: Palgrave Macmillan, 2014).

Wim Muller, 'A Return to the Rule of Law in the South China Sea?', Chatham House, 11 November 2015, available at https://www.chathamhouse.org/expert/comment/return-rulelaw-south-china-sea.

Astrid H. M. Nordin and Mikael Weissmann, 'Will Trump Make China Great Again? The Belt and Road Initiative and International Order', International Affairs, Vol. 94, 2018.

Seo-Hyun Park, 'Changing Definitions of Sovereignty in Nineteenth-Century East Asia: Japan and Korea Between China and the West', Journal of East Asian Studies, Vol. 13, No. 2, 2013.

Thomas Pogge, Global Justice (Hoboken: Blackwell, 2001).

Joshua Rosenzweig, 'State, Society and the Justice Debate in Contemporary China' in Flora Sapio, Susan Trevaskes, Sarah Biddulph, and Elisa Nesossi eds., Justice: The China Experience (Cambridge: Cambridge University Press, 2017).

Ian Shapiro and Lea Brilmayer eds., Global Justice (New York: New York University Press, 1999).

Jie Song, 'Evaluating the Effectiveness of China's Participation in International Legal Matters: Lessons from China's Practice in the International Law Commission and the International Court of Justice', China: An International Journal, Vol. 15, No. 2, 2017.

Tao Song, 'Creating a Bright Future for China-EU Relations Based on Achievement and Success', China Institute of International Studies, 31 December 2012, available at http://www.ciis.org.cn/english/2012-12/31/content 5638039.htm.

Summary of Remarks by Vikram Raghavan, 'Voices from the Outside: Sovereign Equality, International Law, and the Imbalance of Power', Proceedings of the NinetyNinth Annual Meeting of the American Society of International Law, Vol. 99, 2005. 
Ramesh Thakur, 'Conclusion: National Diplomacy and Global Governance', in Andrew F. Coopeter, Brian Hocking and William Maley eds., Global Governance and Diplomacy: Worlds Apart? (Basingstoke: Palgrave McMillan, 2008).

Robert W. Tucker, The Inequality of Nations (New York: Basic Books, 1977).

Gungwu Wang, 'Early Ming Relations with Southeast Asia': A Background Essay', in John King Fairbank ed., The Chinese World Order: Traditional China's Foreign Relations (Cambridge: Harvard University Press, 1968).

Jianwei Wang and Weiqing Song eds., China, the European Union, and International Politics of Global Governance (Basingstoke: Palgrave MacMillan, 2016).

Odd Arne Westad, The Chinese Civil War: Decisive Encounters (Palo Alto: Stanford University Press, 2003).

Pierre-Etienne Will, 'The Chinese Contribution to the Universal Declaration of Human Rights', in Mireille Delmas-Marty and Pierre-Etienne Will eds., China, Democracy, and Law: A Historical and Contemporary Approach (Leiden: Brill, 2012).

Scott Wilson, Tigers Without Teeth: The Pursuit of Justice in Contemporary China (Lanham: Rowman and Littlefield, 2015).

Jan Wouters and Matthieu Burnay, 'China and the European Union in the World Trade Organization: Living Apart Together?', in Jan Wouters, Tanguy de Wilde, Pierre Defraigne and Jean-Christophe Defraigne eds., China, the European Union and the Restructuring of Global Governance (Cheltenham: Edward Elgar, 2012).

Xiaohui Wu, 'No Longer Outside, Not Yet Equal: Rethinking China's Membership in the World Trade Organization', Chinese Journal of International Law, Vol. 10, No. 2, 2011.

X., 'Xi Stresses Urgency of Reforming Global Governance', Xinhua News, 13 October 2015, available at http://news.xinhuanet.com/english/2015-10/13/c 134710464.htm.

Xuetong Yan, 'From Keeping a Low Profile to Striving for Achievement', The Chinese Journal of International Politics, Vol. 7, No. 2, 2014.

Lijun Yang, 'On the Principle of Complementarity in the Rome Statute of the International Criminal Court', Chinese Journal of International Law, Vol. 4, No. 1, 2005.

Dan Zhu, 'China, the International Criminal Court, and International Adjudication', Netherlands International Law Review, Vol. 61, No. 1, 2014. 


\section{GLOBUS Research Papers}

10/2018

Matthieu Burnay and Marta Hermez

Towards Global Justice with Chinese

Characteristics

$9 / 2018$

Katie Verlin Laatikainen and Martin

Palouš

Contested Ground

The Campaign to Enhance the Status of the European Union in the UN General Assembly

8/2018

Hayley Walker

Mutual Recognition in Global

Negotiations

The Case of the 2015 Paris Climate

Summit

$7 / 2018$

Cathrine Holst

Promoting Global Justice when

Backlash Strikes

EU and UN Beijing +20

6/2018

Espen D.H. Olsen

Out but Still In

Norway's Approach to Migration and Asylum as a non-EU State

$5 / 2018$

Samuel Brazys and Krishna C.

Vadlamannati

Aid Curse with Chinese

Characteristics?

Chinese Development Flows and

Economic Reform

$4 / 2018$

Michela Ceccorulli

On Protection and Justice

The Proposals for Reform of the

Common European Asylum System

$3 / 2018$

Ben Tonra

The (In)Justices of Peacekeeping

EUFOR Tchad/RCA
2/2018

Nikola Tomić and Ben Tonra

The Pursuit of Justice through EU

Security Strategies

Sisyphus Redux?

$1 / 2018$

Alexa Zellentin

Different Angles on Climate Justice Insights from Non-domination and Mutual Recognition

$6 / 2017$

Mai'a K. Davis Cross

Europe's Foreign Policy and the

Nature of Secrecy

$5 / 2017$

Bettina Ahrens

The Solidarisation of International

Society

The EU in the Global Climate Change

Regime

$4 / 2017$

Mai'a K. Davis Cross

EU Institutions and the Drive for Peace

The Power of Ideas

$3 / 2017$

Kjartan Koch Mikalsen

Equal Sovereignty

On the Conditions of Global Political Justice

2/2017

Helene Sjursen

Global Justice and Foreign Policy

The Case of the European Union

$1 / 2017$

Franziskus von Lucke

O Justice, Where Art Thou?

Developing a New Take on Climate Justice

$1 / 2016$

Erik O. Eriksen

Three Conceptions of Global Political Justice 


\section{GLOBUS Research Papers}

The GLOBUS Research Papers are pre-print manuscripts on the EU's contribution to global justice as well as the wider question of Global Political Justice. The series is multidisciplinary, with a particular emphasis on the fields of international relations, political science, political theory, sociology and law.

\section{Reconsidering European Contributions to Global Justice - GLOBUS}

GLOBUS is a research project that critically examines the European Union's contribution to global justice. Challenges to global justice are multifaceted and what is just is contested. Combining normative and empirical research GLOBUS explores underlying political and structural obstacles to justice. Analyses of the EU's positions and policies are combined with in-depth studies of non-European perspectives on the practices of the EU. Particular attention is paid to the fields of migration, trade and development, cooperation and conflict, as well as climate change. GLOBUS' team of researchers covers the disciplines of politics, international relations, law, economics, sociology and political theory. The project is coordinated by ARENA Centre for European Studies at the University of Oslo and has partners in Brazil, China, Germany, India, Ireland, Italy and South Africa. It is funded by the Horizon 2020 Programme of the European Union for the period 1.6.2016 - 31.5.2020.

\section{Series Editor}

Helene Sjursen, ARENA Centre for European Studies, University of Oslo GLOBUS Coordinator.

\section{Editorial Board}

Thomas Diez

Erik O. Eriksen

Sonia Lucarelli Pundy Pillay

Ben Tonra
Institute of Political Science, University of Tübingen ARENA Centre for European Studies, University of Oslo Department of Political and Social Sciences, University of Bologna Wits School of Governance, University of Witwatersrand School of Politics and International Relations, University College Dublin 